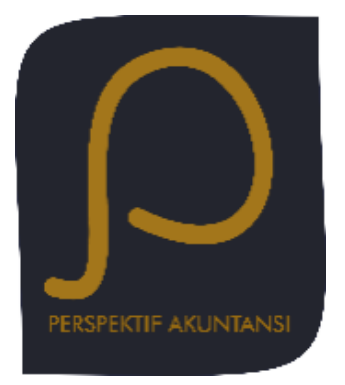

Perspektif Akuntansi

Volume 3 Nomor 2 (Juni 2020), hal. 125-153

ISSN: 2623-0194 (Print), 2623-0186 (Online) Copyright(C) The Authors(s). All Rights Reserved

Fakultas Ekonomika dan Bisnis,

Universitas Kristen Satya Wacana

DOI: https://doi.org/10.24246/persi.vXiX.p125-153

http://ejournal.uksw.edu/persi

\title{
The Sukuk Effect on Stock Return Volatility in Indonesia
}

Legina

Harjum Muharam

Universitas Diponegoro

Ahmad Maulin Naufa ${ }^{1}$

Universitas Gadjah Mada

Received Abstract. The purpose of this research is to examine the effect of the 06/10/2019 announcement of Sukuk issuance on stock return volatility and time the varying volatility that occurs in the movement of stock returns and

Accepted volatility. The data used in this research are daily closing price, and $27 / 06 / 2020$ trading volume incorporates Sukuk issued during the year 2009-2013 in the D-100 D+100 of Observation period. Samples utilized the purposive sampling technique to obtain samples of 13 companies. This study uses the EGARCH (Exponential Generalized Autoregressive Conditional Heteroscedasticity) method of analysis. The results show that the best model for each sample in the EGARCH model is different. The results show that the phenomenon of time-varying volatility occurred in 13 samples. From 13 samples, the event announcement of the Sukuk issuance does not affect the volatility of stock returns except for the Multi Adira Finance company. Furthermore, the trading volume affects the stock returns volatility on nine companies; hence it does not affect the other four companies.

Keywords: Sukuk issuance, return volatility, asymmetric effects, trading volume, EGARCH model.

Abstrak. Tujuan dari penelitian ini adalah untuk menguji pengaruh penerbitan Sukuk terhadap volatilitas return saham dan volatilitas variasi waktu yang terjadi dalam pergerakan return saham dan

1 ahmad.maulin.n@mail.ugm.ac.id 
volatilitas. Data yang digunakan dalam penelitian ini adalah harga penutupan harian, dan volume perdagangan berkaitan dengan Suku yang diterbitkan selama 2009-2013 pada periode pengamatan D-100 sampai $D+100$. Sampel menggunakan teknik purposive sampling yang memperoleh sampel 13 perusahaan. Studi ini menggunakan metode analisis EGARCH (Exponential Generalized Autoregressive Conditional Heteroskedasticity). Hasilnya menunjukkan bahwa model terbaik untuk tiap sampel dalam model EGARCH berbeda-beda. Hasilnya juga menunjukkan bahwa fenomena volatilitas waktu yang bervariasi terjadi pada 13 sampel tersebut. Dari 13 sampel, pengumuman peristiwa penerbitan Sukuk tidak berpengaruh terhadap volatilitas return saham kecuali untuk perusahaan Adira Multi Finance. Sehingga, volume perdagangan memengaruhi volatilitas return pada sembilan perusahaan; namun tidak ada empat perusahaan lainnya.

Kata Kunci: penerbitan Sukuk, volatilitas return, pengaruh asimetris, volume perdagangan, model EGARCH

\section{Introduction}

Regarding financing the companies operationally, the company will always need the fund; it can be obtained from various sources. Firstly, it could be attained from internal capital sources or retained earnings. It also could be gathered from an external source such as loan or debt from the external funding. The company that becomes a public company on behalf of enlarging the operationalization activity fund can obtain the capital from the investors in the capital market. At this moment, the capital market has a function to be the intermediary between the investors and the company they would like to get additional capital by selling their stocks. The Sukuk holders' returns are based on profit-sharing arrangements and the performance of underlying projects, in which, Sukuk investors have undivided and proportionate ownership (Mohamed, Masih, \& Bacha, 2015). There was an impressive development of Islamic financial activities in the world in the last decade, with worldwide Islamic financial assets rising from USD 150 billion in the mid-1990s to USD 1.8 trillion by the end of 2013. This trend has been driven by the growth of Islamic banking activities but also by the expansion of Sukuk. By the end, if 2013, the worldwide value of outstanding Sukuk was 270 billion dollars, representing $14.6 \%$ of global Islamic financial assets (Klein et al., 2017).

Indonesia is a country with the largest Muslim population in the world. It makes the Indonesian company that seeks the additional capital for the company's operational activity from the investors think to the offered-investment is not contradicted with the Islam rules. By the development of the instrument in the financial sector, the sharia obligation appears. The sharia obligation is called Sukuk that it can be one of additional funding alternative on the company. The 
Sukuk is an ownership certificate of an asset (real project) that can be used on a large scale to fund the development of both company and government financing. Therefore, the Sukuk is a useful alternative for cooperation investment, risk-sharing, and asset involvement (real project) that based the Sukuk issuing (Kholis, 2010).

Albeit, the Sukuk is the investment instrument based on sharia instruments that it is believed profitable. Nevertheless, in reality, people or investors do not know or worry about the existence of Sukuk as an investment instrument, both regarding halal and the benefits. From both theoretical and practical perspectives, it is still mostly unknown why firms may choose to consider Sukuk while the overwhelming majorities consistently rely on conventional bond offers (Mohamed, Masih, \& Bacha, 2015). Research to appraise motivations to issue specific Sukuk type remains limited-fewer studies of Sukuk (Ibrahim, 2015). The development of the Sukuk market has been most encouraging in recent years. The difference between Sukuk and general obligation is the ownership asset that is one of the primary products in Islamic finance. Sukuk owners have the part from the underlying asset in some Sukuk transactions based on how much their investment in their owned-stocks. On the general obligation, the mandatory debt which issued to the obligation holders from the issuer as the debt evidence. No ownership in the business, joint venture, or the project that is given to the obligation holders. As a result, the Sukuk as the part project, business, or a collaborating business in the general obligation that represents the stock on the total debt.

As presented above, the issuing of Sukuk every year is increasing significantly by the year. The Indonesian company that issued Sukuk firstly is the Indosat Company with Mudharabah Sukuk in 2002 by the number of emission value is 175 billion rupiah. In Table 1, the number of issuing Sukuk is increased cumulatively by the time. Based on that Table, in September 2013, some issuing corporate Sukuk achieved 61 issues by the total value of emission is 11.41 trillion rupiah. From 61 corporate Sukuk issuing's, the outstanding Sukuk produced 33 corporate Sukuk with the value of 6.9 trillion rupiah. It proved that Sukuk is becoming more favorable by the company as the operational funding alternative.

The investment surely pays attention to two things: the return and the risk. Investors want higher returns and lower risk. From the static trade-off theory point of view, more profitable firms are exposed to lower risks of bankruptcy and have greater incentive to employ debt to exploit interest tax shields, hence expect a positive relationship (Mohamed, Masih, \& Bacha, 2015). Therefore, the higher actual return than the expected return, the more significant risk on that investment. There are two types of strategy that can be used for the investors 
to gain their desirable return as the result of their investment 1 ). The contrarian strategy 2). Momentum investment strategy. The contrarian investment strategy is a condition where the investors are buying the stock at a lower price and selling it at a higher price to attain the specific capital gain. The momentum strategy is the strategy where buying the winner stocks than sell them when the price is higher. Both strategies have the similarity that both are similar in the use of market information as a basis for decision making in the market trading at the capital market.

Table 1. The number of total values, emission, and outstanding Sukuk

\begin{tabular}{rcccc}
\hline \multirow{2}{*}{ Year } & \multicolumn{2}{c}{ Sukuk emission } & \multicolumn{2}{c}{ Outstanding Sukuk } \\
\cline { 2 - 5 } & $\begin{array}{c}\text { Total value } \\
\text { (billion IDR) }\end{array}$ & $\begin{array}{c}\text { Total } \\
\text { number }\end{array}$ & $\begin{array}{c}\text { Total value } \\
\text { (billion IDR) }\end{array}$ & $\begin{array}{c}\text { Total } \\
\text { number }\end{array}$ \\
\hline 2002 & 175 & 1 & 175 & 1 \\
2003 & 740 & 6 & 740 & 6 \\
2004 & 1414 & 13 & 1394 & 13 \\
2005 & 2009 & 16 & 1979 & 16 \\
2006 & 2282 & 17 & 2179 & 7 \\
2007 & 3174 & 21 & 3029 & 20 \\
2008 & 5498 & 29 & 4958 & 24 \\
2009 & 7015 & 43 & 5621 & 30 \\
2010 & 7815 & 47 & 6121 & 32 \\
2011 & 7915 & 48 & 5876 & 31 \\
2012 & 9790 & 54 & 6883 & 32 \\
2013 Jan & 9790 & 54 & 6883 & 35 \\
Feb & 10169 & 57 & 7262 & 38 \\
Mar & 11294 & 60 & 8387 & 37 \\
Apr & 11294 & 60 & 7817 & 37 \\
May & 11294 & 60 & 7817 & 36 \\
Jun & 11415 & 61 & 7538 & 33 \\
Jul & 11415 & 61 & 6974 & 33 \\
Aug & 11415 & 61 & 6974 & 33 \\
Sept & 11415 & 61 & 6974 &
\end{tabular}

Source: Financial Services Authority/Otoritas Jasa Keuangan Indonesia (OJK)

There are some differences between strategies in terms of information clarity in the market related to the company's stock. On the contrarian strategy, the investors must pay more attention to specific information regarding the specific information of the company. On the contrary, the momentum investment strategy the investors take the decision when the obscurity information occurs.

The cutting-edge of information development makes the possibility for an investor to obtain the capital market information very quickly and correctly. The investors would seek the information accurately and detail about the current and the future. The current financial theory often refers to the efficient market hypothesis theory. The market efficiency is based on the speed of stock price, reflecting all the available relevant information in the market. Financial markets in emerging economies are expected to be not as efficient as in more 
advanced economies, and leakage of information is likely when new securities are about to be issued (Godlewski et al., 2013). The event study is an observation of the stock price movements in the capital market to understand whether the abnormal return is related to some events. The event study aims to measure the relationship of the event that affects the stock return.

Meanwhile, the event study aims to measure the impact of an economic event like merger and acquisition, profit announcement, debt-equity issuing, and other macroeconomic events. The new information or event occurred would impact the stock price movement, which is issued. Therefore, the stock price would be affected.

The company which issued the sharia bonds tends to be smaller than the conventional bond issues. The results presented that issuing sharia bonds is responded negatively by the markets where it reflected the lower cumulative abnormal return (CAR). Nevertheless, the market has a positive reaction to the Sukuk announcement. Thus, it is good news to investors that it would give the advantage and profit to the investors. Then, the announcement of Sukuk issuance contains relevant information to the investors as the good news so that it would enlarge the investor wealth. The momentum of Sukuk issuance must be the highly strategic information, the challenges, and the sustainable development opportunities for businesses and the financial sector - Islamic finance. The information event test is conducted to measure the effect of the Sukuk issuance announcement on the return stock level, to see who investors are reacting to this event.

The test regarding information content is intended to see the market reaction due to the announcement. If the announcement contains relevant information, the market will react to the expected announcement that is received by the market. The market reaction could be seen from the relevant securities price changes. It can be measured using return as the value of price changes or using the abnormal return. By using abnormal returns, we can capture the effect information to the market.

On the contrary, pecking order theory considers the problem of information asymmetries in which shareholders/managers of a firm know more about the value of its assets in place and future growth prospects than do the outside investors (Mohamed, Masih, \& Bacha, 2015). The relationship between the company's information and the company's performance varies significantly. Theoretically, there is a positive relationship between disclosure and market company performance. The Sukuk issuance of sharia is indicated as one of the disclosures toward the company's funding strategy, so it would influence the investment decision, which would be reflected in return. It is because the 
issuance of Sukuk gave one more value to both firms and the countries on behalf of the company expansion and country development.

The volatility is a responsiveness measure from the security or portfolio. There is a relationship between stock return and volatility in the time series data, which is a random walk because share return at the time already reflects all relevant information to the value of existing assets. The stock return would change if there were entirely new information, and it was unexpected. The new information commonly would be responded by the investors in the short time frames that encourage the stock to return to the equilibrium condition. The risk-neutralizing effect of a convertible features smaller, riskier, growth firms for convertible bond issuers (Mohamed et al., 2015). There have been conducted many studies about the stock return and its volatility to prove that the stock return in many countries presented volatility time-varying (the return volatility is random at any time).

Modeling the volatility of time-varying, a predictive and forecasting method has been developed based on the econometrics base, which is called Autoregressive Conditional Heteroskedasticity (ARCH), which is explicitly designed to model and forecast the conditional variance. Engle introduced the ARCH model in 1982, then developed by Borislav in 1986, later known as the Generalized Autoregressive Conditional Heteroscedasticity (GARCH). Now, both models are prevalent and developed in some studies. The investors would absorb the emergence of remaining issues or information in the market that it would be interpreted differently among the investors; some believe it is good news while others believe as bad news. Both bad and good news would affect the different volatility, which is called the asymmetric effect or leverage effect. It happens if there were good and bad news that would impact equally or differently to the return volatility of the stock.

The return volatility of stock faced the time-varying phenomenon; nevertheless, the asymmetric or leverage effect did not occur. In contrast, the stock return has time-varying volatility and asymmetric or leverage effect on the return volatility of the stock. Few studies used GARCH methods in the analysis (Bhuiyan et al., 2018). On the Sukuk announcement, the Sukuk has not been able to be predicted whether it is bad or good news, or it is nothing for the investors in the capital market.

The event that occurred in the company would influence the trading volume, which affects the stock price of that company, the price movement would impact to the stock price volatility. The trading volume of stock would attract the investor interest to invest due to the prospect. Therefore, it directly would influence the stock return of those shares. The trading volume of stock would 
be used as the measure to see whether the investors evaluate the announcement as a positive or negative signal regarding affecting the trading volume above the normal. The trading volume of stock influences the stock return. Albeit, the trading volume of shares does not affect the stock return. Based on the description above, we would examine how big the influence of the event announcement of Sukuk issuance to the stock return volatility.

Based on those backgrounds, there are problems in this research as the existence of a research gaps from the different findings researchers Sukuk announcement event (Khartabiel et al., 2019) on return volatility (Naufa et al., 2019), time-varying volatility (Bhuiyan et al., 2019), asymmetric effect (Aloui, Hammoudeh, \& Hamida, 2015), and the trading volume of the stock (Wilson, 2008). Some researchers find that Sukuk issuance increases those variables (Haroon et al., 2019; Klein et al., 2017), while other researchers argue that Sukuk announcement reduces those variables (Bhuiyan et al., 2018; Hanefah \& Sains, 2013). On the other hand, there are some researchers who discovered that Sukuk has no impact on those (Godlewski et al., 2013; Smaoui et al., 2019). Those different findings indicate that there is a gap of research from debatable impacts of Sukuk announcement of those variables, hence it is necessary to conduct the research about this issue, in particular in emerging context, Indonesia that is different compared to other developed countries.

This research offers some new settings such as 1). How those relationships in the Indonesian context as a unique context and one of the emerging markets in the world 2). This paper also discusses new issues related to time-varying volatility, asymmetric and leverage effect, and trading volume to explain the relationship between Sukuk issuance and return volatility 3). Most of the financial studies discuss the effect of the conventional bond (obligation) on return volatility, while the impact of Islamic bond (Sukuk) on return volatility that to best our knowledge is limited in an emerging market.

Therefore, by those, we formulated some research questions as follows: 1). How the influence of the Sukuk announcement event on the return volatility of stock? 2 ). Whether the time-varying volatility occurs at that event? 3). Whether the asymmetric or leverage effect happens to the stock return volatility? 4). Whether the trading volume trading influence the stock return volatility in Indonesia?

This research aims to examine those phenomena through the research process. In contrast, the research uses are for the improvement of scientific research, particularly Islamic finance, and the resolution of problems and policy in this field. The aims of this research are 1). To examine how the influence of the Sukuk announcement on the return volatility of shares; 2). To understand 
whether the time-varying volatility occurs at that event; 3). To understand whether the asymmetric or leverage effects on the stock return volatility; 4 ). To find out whether the trading volume influences the return volatility of the stock.

The research contributions are: 1) for the potential investors, this research can help to provide information to them as the consideration matter before the decision regarding investment. 2). For the company, this can provide an understanding of the Sukuk announcement effect to the return volatility of stock for the corporation that issued that Sukuk. 3). For the academics, this hopefully contributes to the development of financial management about the sharia bonds (Sukuk). The writing systematic in this research is arranged in several chapters: the introduction, the literature review, research method, results and discussion, and conclusion.

\section{Literature Review}

\section{The Theory Basis - Capital Market Definition}

The capital market is defined by the market for any financial instrument or the long-term security that can be traded, debt, and capital, from the government, public authorities, or the private companies. The capital market runs two functions: economic and financial. The economic function from the capital market is the facility that facilitates to transfer funds from the side who exceed the money (lenders) to the side who need the money (borrowers). While the financial function is done with providing the necessary money to the borrowers, while the lenders provide the fund without directly involved in the ownership of real action, which is needed for investment. Sukuk represents the backbone for the development of a much needed secondary Islamic capital market; the vast majority of the instruments are held by Islamic banks (Godlewski et al., 2013). Although Sukuk has been dominating the Malaysian capital market, the motivations of the firms issuing Sukuk or conventional bonds remained mostly unexplored (Mohamed, Masih, \& Bacha, 2015). Therefore, Islamic banking and Islamic capital market become subjects of increasing empirical inquiries (Ibrahim, 2015).

Islamic banks provide an alternative mode of financing compared to conventional banking, Sukuk is similar in structure to conventional bonds but allow sovereign and corporate entities to raise funds in capital markets in conformance with Sharia principles (Godlewski et al., 2013). There are some functions of the capital market for the economy of the country as follows: 1). Saving function: the savers need to think about the alternative saving beyond the bank-capital market. The valuable letter traded in the capital market give an affordable and accessible way, without risk to invest their fund. 2). Wealth 
function: the capital market is one way to save wealth for either long-term or short-term until it can be reused. This way is better because the wealth in the valuable letterform is not depreciated like another asset like building or cars. 3). Liquidity function: the capital market can liquidate the wealth saved in the valuable letters with a lower risk than the other asset. The liquidation process of the valuable letter is relatively more affordable and faster. 4). The credit function: the loan can be a loan to consumption or investment. The capital market for the economy in the country is a development funding resource for the loan, gathered from society. The government supports the growth of the capital market to attain the fund, and it is more affordable.

In this context, Islamic finance, specifically the fixed-income instruments defined as Sukuk, is now an essential part of the mainstream global financial system (Bhuiyan et al., 2018). The last decade witnessed a vast expansion of Islamic finance in Middle Eastern and Southeast Asian countries. Sukuk issues, which are Islamic financial instruments structured to replicate the cash flows of conventional bonds, have notably proliferated, fueling the debate on the similarity between Islamic and conventional finance (Godlewski et al., 2013).

\section{Sharia bonds (Sukuk)}

Sukuk is an alternative mode of financing to bonds that are compliant with Islamic law (Sharia). Sukuk is an investment certificate which can be issued by companies and countries, with similarities and differences with bonds. Like bonds, Sukuk has a maturity date and provide income flows over the life of the security with a payment at maturity to their holders. Unlike bonds, the value of Sukuk is not based on the creditworthiness of the issuer, as holding Sukuk, shares represent the ownership of tangible assets, usufruct, or services of revenue-generating issuers. As a consequence, Sukuk prices can vary the creditworthiness of the issuer and with the market value of the underlying asset. Sukuk can be structured like debt-based instruments or partnership contracts. Debt-based instruments such as Ijara (rent/lease agreement) and Murabaha (cost-plus sale) do not contain strict sense interest, but they pay a predetermined rate of turn to investors. Musharaka and Mudaraba are partnership contracts in which the financier and the entrepreneur share profits based on pre-agreed ratios, whereas losses are commensurate to their contribution to the partnership (Klein et al. 2017).

Standard Chartered and Deutsche Bank are the two other international banks with increasing experience of managing Sukuk, a natural development given their primary role in conventional bond, note, and bill management (Wilson, 2008). In Islamic financial markets, it is well known that sharia-compliant stocks and Sukuk (Islamic bonds) are primary investment instruments for 
constructing optimal Islamic and non-Islamic investment portfolios (Aloui, Hammoudeh, \& Ben, 2015). Sukuk is different from other existing debt instruments since it has the characteristics of both debt and equity. Without any specific reference to any Sukuk underlying contracts, Sukuk-investors are generally paid dividends on the outcome of profit-sharing agreements, instead of fixed interest installment payments as in conventional bonds. Consequently, this profit-sharing type of financial tool depends much on the internal information of the issuers when Sukuk-investors would like to receive a maximum dividend (Mohamed, Masih, \& Bacha, 2015). The sharia obligation called 'Sukuk' is from the plural word of Sakk-an Arabic word, which means the certificate. The Sukuk is not the new word in Islam, that word is well-known since the middle age, where the Muslim society used in the context of international trade. International traders have used it. The traders trade it at the time as the document that documented the financial obligation due to the trade business and other commercial activities. Thus, the number of western writers who have a concern related to Islamic history and Arabic people stated that the sake is the root of the word 'cheque' in the Latin language. Which now becomes something that is commonly used in contemporary banking world transactions.

According to sharia standards Number 17 about the investment, it has defined that: "the Sukuk investment is a certificate of equal value, representing undivided shares in ownership of tangible assets, usufruct, and services or (in the ownership of) the assets or a particular project or special investment activity. However, this is true after receipt of the value of the Sukuk, the closing of subscription and employment of fund received for the purpose Sukuk issued". While, according to the rules Number 9.13 results from Bapepam LK Number: Kep-13/BL/2006 about the Sukuk issuance, which the Sukuk means the sharia securities that can be a certificate or the ownership which is valuable equally representing the part of involvement that it cannot be separated or divided for 1). The ownership of tangible certain assets 2 ). The benefit value and the service toward the project of a specific asset or the specific activity investment 3). The ownership is a project of a specific asset or certain investment activity. According to the Statements from DSN-MUI Number 32/DSN-MUI/IX/2012; Sukuk is defined as the sharia obligation as a long-term letter based on the Islamic principles. The issuers issue Sukuk to the Sukuk holders that obligate the issuers to pay the income for the Sukuk holders, in terms of return or margin fee and pay back the obligation fund at the due date. 


\section{Stock}

The stock is one of the valuable instrument letters, which is dominant in the capital market. In Islamic financial markets, it is well known that shariacompliant stocks and Sukuk (Islamic bonds) are primary investment instruments for constructing optimal Islamic and non-Islamic investment portfolios (Aloui, Hammoudeh, \& Ben, 2015). Whether stock market investors react differently to the announcements of Sukuk and conventional bond issues. The stock market is neutral to announcements of conventional bond issues, but it reacts negatively to announcements of Sukuk issues. The attribute of this finding to the excess demand for Islamic investment certificates and to an adverse selection mechanism that favors Sukuk issuance by lower-quality debtor companies (Godlewski et al., 2013). Other researchers studied the Sukuk issuance to the stock market reaction, whether the negative stock market reaction persists over time (Klein et al., 2017). The empirical evidence indicates a strong dependence between these sharia stock and Sukuk indexes (Aloui, Hammoudeh, \& Hamida, 2015a).

\section{Stock Return Events}

The stock return could be obtained from the stock price of security $i$ at the time $t\left(\mathrm{P}_{i, t}\right)$ is minus by the stock price of security $i$ at the time $t-1\left(\mathrm{P}_{i, t-1}\right)$ divided by the stock price of security ${ }_{i}$ at the time $t-1\left(\mathrm{P}_{i, t-1}\right)$. It can change anytime, so the investors or the prospective investors need to know in detail when they choose the stock as the investment choice. Since capital-raising using bond or Sukuk issuance requires the Indonesian capital market regulator's approval, the estimation period and event window are expected to be sufficient for any abnormal returns to be observed (Mahomed et al., 2018). They used the estimation period--180 days to 41 days prior to the event. While Klein, Weill, and Godlewski (2017) examined the abnormal stock return in their event study research, where they used an estimation period of 90 working days from -11 to -100 days before the issuance.

\section{Stock Return Volatility}

Abnormal stock return is a proxy of return volatility by using the stock return minus the expected return (Klein et al., 2017). In terms of the quality of the Sukuk index performance based on both return and risk, it is evident that Sukuk performed well, with lower volatility and a higher Sharpe ratio (Bhuiyan et al., 2018). Some researchers investigate the volatility and dynamic correlation transmission mechanism between the sharia stock prices and Sukuk within the global GCC market, with consideration to global financial crises (Aloui, Hammoudeh, \& Hamida, 2015). Investors in Ijara Sukuk are not only concerned 
with average returns, but also with the volatility of the returns as lower volatility will generally be preferred to higher volatility by the risk-averse (Wilson, 2008).

\section{Trading Volume}

The volume of issued corporate bonds is substantial and allows a comparison between the issuance of corporate Sukuk and bonds. Malaysia is the country with the world's biggest country of issuance for corporate Sukuk. In addition, the volume of issued corporate bonds is substantial and allows a comparison between the issuance of corporate Sukuk and bonds (Klein et al., 2017). The trading volume is an appropriate proxy for market liquidity, which also can reflect investors' sentiment and the environment of the global market (Aloui, Hammoudeh, \& Hamida, 2015). The volume of Sukuk issued in Malaysia alone in 2007 was $\$ 28.1$ billion, compared to $\$ 19$ billion for all GCC countries. The volume of Sukuk issued in Malaysia alone in 2007 was $\$ 28.1$ billion, compared to $\$ 19$ billion for all GCC countries (Godlewski et al., 2013). According to Bloomberg Professional Services, trading volumes for the ten most liquid Sukuk are significantly lower than other fixed income markets. The bid-ask spread, as a liquidity risk indicator in the Sukuk market, has a large impact on timevarying correlations. The impact increases with rising price volatility and lowers the trading volume. It is also a proxy of investor uncertainty that leads to higher correlations due to frequent portfolio reallocations (Hassan et al., 2018).

\section{The Effect of Stock Movement on The Time-varying Volatility Phenomenon}

The financial data always have a random walk pattern; therefore, they will impact the volatility by the time. The volatility fluctuation by the time surely would change either increase or decrease. The volatility is the deviation or the standard deviation of return on the financial instrument, which can be made as to the risk measure. Time-varying volatility is the implication of volatility from the subject that swing primarily on the stock or other financial instruments, which presents the higher or lower volatility period on any period points. Hassan et al., (2018) adopt a multivariate GARCH framework to examine conditional correlations and volatility linkages between Sukuk (Islamic bonds) and conventional bond markets in Europe, the United States, and emerging markets. We find that Sukuk and conventional investment-grade bonds have a lower reaction of conditional volatility to market shocks and higher persistence; we also find that Sukuk returns are much less volatile than U.S. and EU investment-grade bonds. Further, we find a time-varying, positive, 
conditional correlation between Sukuk returns and leading bond markets, which is driven by changing macroeconomic and market conditions.

The asymmetric effect or the leverage effect is the decrease or increase return remarkably, which is followed by the higher volatility. It can occur if there is an effect on the volatility toward the availability of information which is good or bad news. In the measuring of asymmetric effect, we could use the Exponential GARCH (EGARCH). If the market absorbs the information as the good news, it will make positive volatility changing. While, if the information absorbed by the market is bad news, the volatility tends to be negative. The asymmetric information would impact the volatility because it is the effect which is occurred due to the information. In this research is the Sukuk announcement valued by the investors as either the right or bad news. It also may not be responded to by the investors. It will appear if the absolute return has asymmetric information, both positive or negative. According to (Klein et al., 2017), Theoretical literature provides opposing arguments on the impact of debt issues on firm performance. Two hypotheses may explain a positive impact on firm performance. First, issuing debt is a signal solving adverse selection issues. Namely, information asymmetries between firm insiders and outsiders create an adverse selection issue. High-quality firms have then incentives to send a signal to show their quality. Debt represents a credible signal. Issuing debt is costlier for the firm's insiders in a low-quality firm than in a high-quality firm, due to the probability of default in case of bad performances. Shareholders are then expected to react positively to a bond issue, which reveals promising prospects for the firm's profitability.

\section{Hypotheses Development}

Based on a literature review, the framework of thought and previous research on the implementation of an event study in which this is the Sukuk announcement, the hypothesis in this study can be arranged as follows:

The research on the difference between Sukuk and other conventional bonds is to see the stock market perspective. They found that the investors would react. Differently, some investors do not react to the common bonds, while others react significantly to the bonds. Furthermore, the value and rate of Sukuk issuance do not affect the CAR both simultaneously and partially. Some studies found no effect of bond issuance to the CAR. Klein, Weill, \& Godlewski, (2017) show that the mean and median CARs of Sukuk issues are significantly negative for all event windows, except for the event window $[0,0]$ for which the mean CAR is negative but not significant. In the case of bond issues, the mean CAR is not significant or significantly positive, depending on the event window. These 
first results tend to suggest a more detrimental market response for Sukuk issues than for bond issues.

H1: there is a negative influence of the Sukuk announcement on stock return volatility.

On the contrary, the trading volume influences stock return. If the stock trading volume increases, then the stock return will also increase. Moreover, vice versa, if the stock trading volume decreases, the stock return will undoubtedly decline. Godlewski, Turk-ariss, \& Weill (2013) use an event study methodology to compare the stock market reaction to the announcements of Sukuk and bond issues of companies in Malaysia. They find that the stock market reaction is neutral to the announcement of bonds but that investors react negatively to the announcement of Sukuk. The negative implications of Sukuk issues are attributed to two reasons. First, an adverse selection mechanism can be at work, as borrowers with the lowest return expectations may favor the issuance of profit-and-loss sharing Sukuk structures over conventional Interest-based bonds. Second, there is an excessive demand for Sukuk coming from Islamic institutions. As a result, it can be easier for a firm to issue and sell Sukuk relative to bonds. Issuing Sukuk would then be interpreted to obtain financing when the company is unable to issue a bond.

H2: stock return movements will experience the phenomenon of varying volatility.

The difference between this research and previous research is as follows: 1). In this study, it was using the Sukuk announcement event, which is still rarely used in research. By looking at movements in stock price movements that will affect stock returns. Also, this study will look at the market reaction and market return volatility. Whereas in previous studies, it has not been explained. 2). In this study using the latest data sample, the price at the time of the announcement event occurred on the $\mathrm{H}-100$ and $\mathrm{H}+100$ announcements. The companies used in the study were companies that issued Sukuk announcements in the period 2009-2013, which were listed on the Indonesia Stock Exchange.

H3: there is an asymmetric effect or leverage effect on stock volatility.

H4: there is an influence of stock trading volume on stock return volatility. 
Then, those hypotheses of this research can be depicted in the framework shown in Figure 1 as follows:

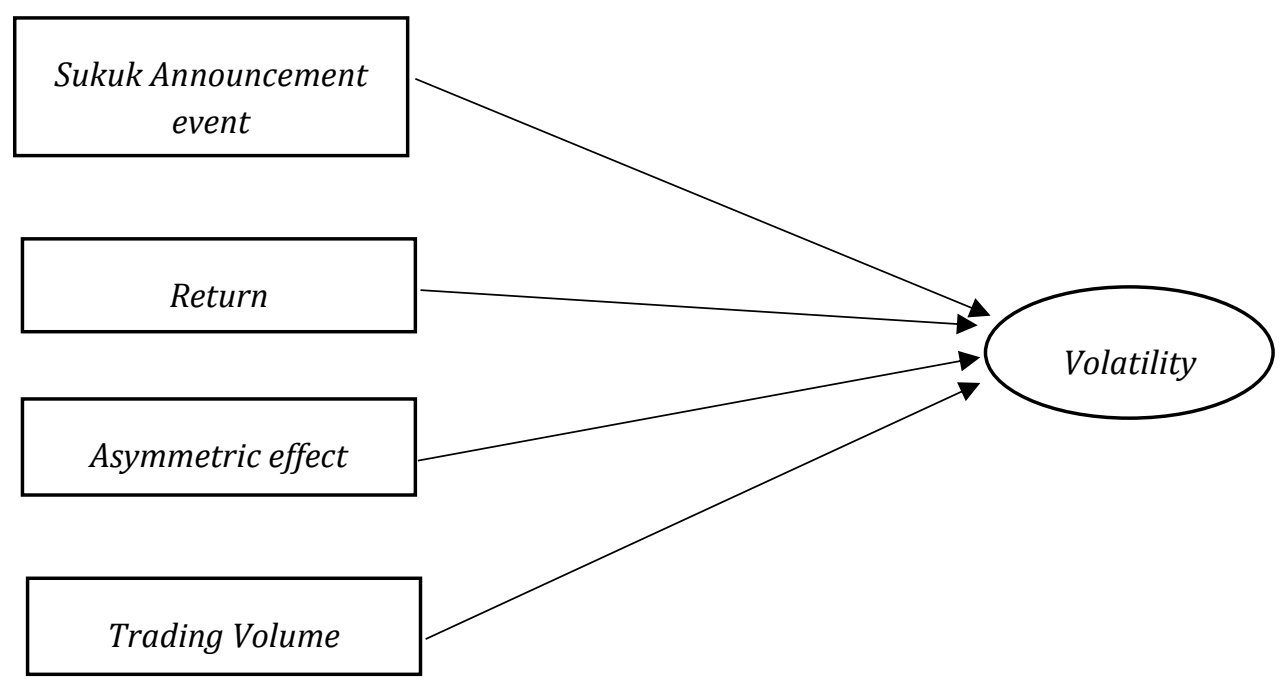

Figure 1. Mind Mapping

\section{Methodology}

The population used in this study is the overall Sukuk announcement issued by the company on the Indonesia Stock Exchange (IDX). We follow some previous studies like Hassan et al. (2018), who collect daily data for 68 highly liquid Sukuk issuance listed in the major Islamic and non-Islamic markets (Bursa Malaysia, Nasdaq Dubai, and the London Stock Exchange). The sample is part of the population that is taken through certain ways that have specific characteristics, transparent, and can be considered to represent the population that is used in the study. Hassan et al. (2018) construct an index of such instruments with the same Bloomberg methodology and criteria to avoid selection bias in our analysis. By studying the sample, we will be able to draw conclusions that can be generalized to the study population. The way in sampling is the process of selecting enough elements from the population, so that research on samples and an understanding of their properties or characteristics can generalize these characteristics or characteristics to the population element.

Sample selection is made by a purposive sampling method. The purposive sampling method is a method by setting criteria in the sample. The sample used in this study is the announcement of corporate Sukuk listed on the IDX for the period 2009-2013. The criteria for this sample are as follows: 1). A company listed on the IDX or a company that goes public 2). 2. Companies that announce Sukuk in 2009-2013 3). The data used in the calculation basis are daily data, 
both for price shares, which will be used as a daily stock return calculation. 4). The daily stock price data used is the daily stock price at the time opening and closing stock price

The data used secondary data. Secondary data is data obtained from other parties in the form of data made or published to the public or the public. Secondary data used in this study were obtained from the Indonesia Stock Exchange, Bloomberg, the Financial Services Authority, newspapers, and other literature related to this research. This step follows some previous studies which utilized data covering Sukuk and bond issuance. The accounting data (Klein et al., 2017), corporate bond index (Hassan et al., 2018), issues of Sukuk and bonds come from Bloomberg and Spans (Godlewski et al., 2013).

The method of data collection carried out in this research is the decenter method which is a method by collecting the data needed such as time series preevent to post-event the company's Sukuk announcement, pre-event stock trading volume up post-event announcements of Sukuk companies, journals, daily newspapers and other literature related to objects in this study. Mahomed, Ramadilli, and Ariff (2018) gathered the data of abnormal returns around the announcement date. Other research used time series data for studying the Sukuk (Bhuiyan et al., 2018). While Mohamed, Masih, and Bacha (2015) utilized panel data of Sukuk.

\section{The Operationalized Variables}

The variables in this study include the dependent variable and the independent variable. The dependent variable is a variable that has characteristics where many factors influence the size of the variable. While independent variables are variables that can stand alone without being dependent or influence by other factors. They are 1). Independent variables used in this study are the announcement Sukuk issuance and stock trading volume. 2). Dependent Variables: The dependent variable used in this study is volatility stock returns. This study follows some previous studies like (Mahomed et al., 2018; M. Mohamed et al., 2017) examined the announcement of Sukuk issuance as the independent variables. Aloui, Hammoudeh, and Hamida (2015) include trading volume as an exogenous or independent variable. While, some other researchers treated the volatility as the dependent variable (Bhuiyan et al., 2018).

The operational definition of variables in this study is each variable used in the study. The usefulness in the use of operational definitions is the basis for collecting data so that in the study, there is no bias towards the data taken. Also, in practical use, operational definitions can also eliminate bias in interpreting ideas or intentions, which are usually in written form. The variable indicators 
in this study are as follows: 1). Independent Variables: Independent variables in this study are the announcement of Sukuk issuance and stock trading volume. The announcement of Sukuk issuance defined as news or event when Sukuk is announced to the capital market. This announcement uses a dummy variable where one is before the $\mathrm{H}-0$ announcement or event date. Moreover, 0 for after H-0 or the data event. Trading volume is defined as the number of all shares traded in the capital market. 2). Dependent Variables: The dependent variable in this study is the volatility of stock returns. The volatility of stock returns is an indicator of uncertainty or an investment in the form of shares. The definition of operationalized variables can be formulated as follows, to measure the volatility of returns shares:

\section{Table 2. The definition of operationalized variables}

\begin{tabular}{|c|c|c|c|c|c|}
\hline No. & Variable & $\begin{array}{c}\text { Operationalized } \\
\text { variable }\end{array}$ & Measure & Source & Scale \\
\hline 1. & $\begin{array}{c}\text { Return } \\
\text { volatility }\end{array}$ & $\begin{array}{l}\text { An indicator of } \\
\text { uncertainty or } \\
\text { from an } \\
\text { investment in } \\
\text { the form of } \\
\text { shares }\end{array}$ & $\begin{array}{l}\text { return volatility } \\
=s t d \log \frac{t_{q}}{t_{q-1}}\end{array}$ & $\begin{array}{c}\text { Secondary } \\
\text { data }\end{array}$ & Ratio \\
\hline 2. & $\begin{array}{c}\text { The event of } \\
\text { Sukuk } \\
\text { announcement }\end{array}$ & $\begin{array}{l}\text { Events when } \\
\text { Sukuk are } \\
\text { announced to } \\
\text { the capital } \\
\text { market }\end{array}$ & $\begin{array}{c}\text { Use a dummy } \\
\text { variable where } 1 \\
\text { is for } \\
\text { announcements } \\
\text { before t- } 0 \text { and } 0 \\
\text { for the } \\
\text { announcement } \\
\text { after t- } 0\end{array}$ & - & - \\
\hline 3. & $\begin{array}{l}\text { Trading } \\
\text { volume }\end{array}$ & $\begin{array}{c}\text { The total } \\
\text { number of } \\
\text { shares of } \\
\text { companies } \\
\text { traded in the } \\
\text { capital market }\end{array}$ & $\begin{array}{c}\text { Number of } \\
\text { shares in a whole }\end{array}$ & $\begin{array}{c}\text { Secondary } \\
\text { data }\end{array}$ & Ratio \\
\hline
\end{tabular}

The data analysis technique used in this study is the GARCH method to test the effect of Sukuk announcements on stock return volatility. Where in this study measures the stock return, trading volume, and Sukuk announcement event. The method of analysis in this study using descriptive analysis, stationarity test, classic assumption test, normality test and autocorrelation test, analysis model of GARCH to EGARCH form (Exponential Generalized Auto-Regressive Conditional Heteroscedastic), hypothesis test, and z-statistical test. 


\section{Event Study}

Event study depicts one financial research technique that makes the possibility to one observer values the impact of an event to the inevitable stock price changing. Event study method regarding the stock field is introduced firstly by Stephen J. Brown in 1985 "Using daily stock returns: The case of event studies". Nonetheless, there are limited papers that studied Sukuk by using event study (Godlewski et al., 2013; Klein et al., 2017; Mohamed et al., 2015). In particular, in Indonesia (Mahomed et al., 2018). Godlewski, Turk-ariss, and Weill (2013) used an event study methodology on a sample of Malaysian listed companies. The reaction can be measured by using the return. If the abnormal return occurs, we can say that the announcement contains the information content so that it would give the abnormal return in the market. While, if there is no information content, it will not give the abnormal return. Klein, Weill, and Godlewski (2017) state that one of the bad events for the evolution of the firm performance is Sukuk, especially to the stock market investors. Therefore, Sukuk issuance has a negative stock market reaction. To issue Sukuk would act as a signal of the bad financial shape of the issuer, in line with the adverse selection argument stressed before. Alternatively, it can also contribute to deteriorating the situation of the firm if such an event is more closely than the issuance of a bond.

\begin{tabular}{lll}
\hline Event & $\begin{array}{l}\text { Market reaction toward the } \\
\text { information content }\end{array}$ & Result \\
\hline
\end{tabular}

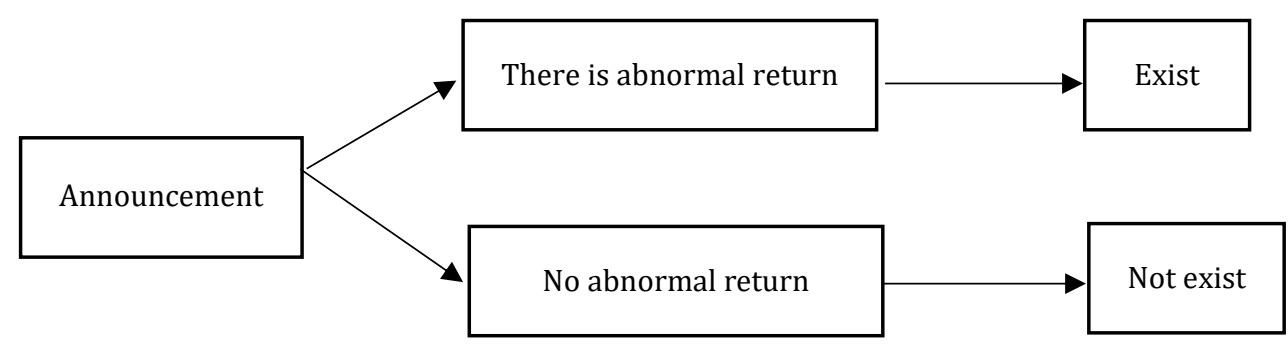

Figure 2. The Information Content of An Announcement 


\begin{tabular}{llll}
\hline Event & $\begin{array}{l}\text { Information } \\
\text { content }\end{array}$ & Speed of reaction & $\begin{array}{l}\text { market efficiency } \\
\text { based on the } \\
\text { information }\end{array}$ \\
\hline
\end{tabular}

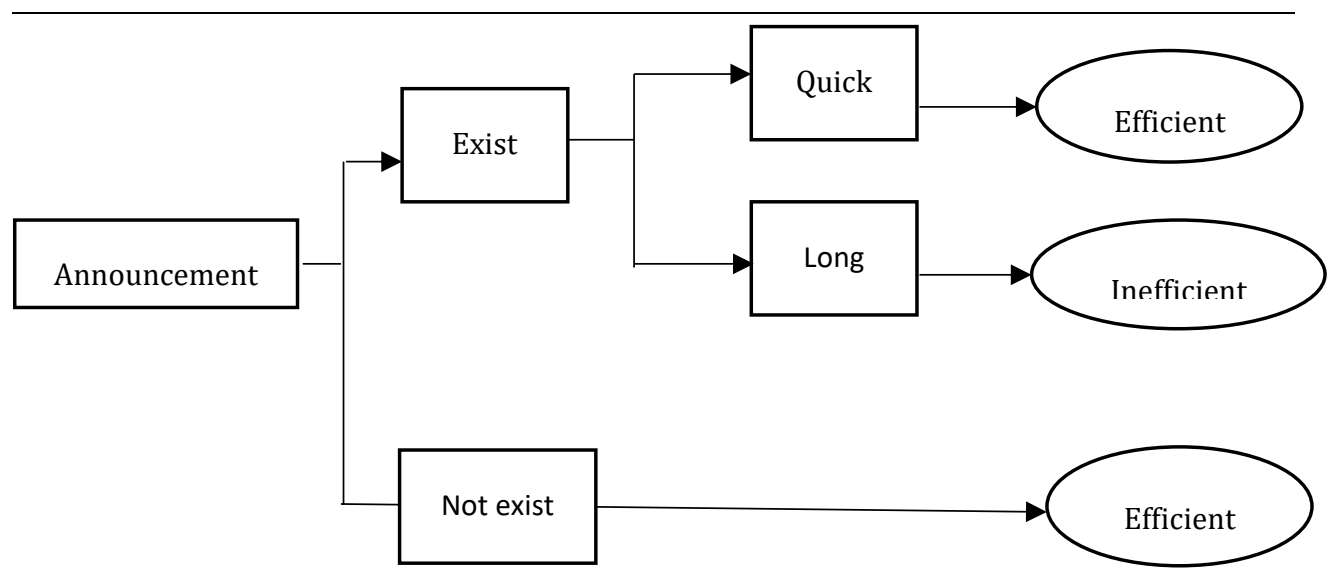

Figure 3. The Market Efficiency based on The Information

\section{The analysis technique and hypothesis testing of stationarity}

Aloui, Hammoudeh, and Hamida (2015) implement some conventional unit root and stationarity tests for all the selected Islamic indexes. Following the Augmented Dickey-Fuller (ADF) and the Phillips-Perron (1988) (PP) unit root tests, we can undoubtedly reject the hypothesis of a unit root for time series returns at the $1 \%$ significance level. While, if the time series is non-stationarity, it could be the problems of analysis. Hassan et al., (2018) also performed the stationarity test for all investigated bond indexes. The conventional unit root and stationarity test results for the Sukuk and sharia-stock time series. Three alternative tests are implemented, namely the Augmented Dickey-Fuller (1979) (ADF), Phillips and Perron (1988) (PP), and Kwiatkowski et al. (1992) (KPSS) tests. From the results of the ADF and PP tests, it can be noted that both the sharia stock and Sukuk indices are non-stationary at the significance level of $1 \%$, but their first order differences are stationary (i.e., the sharia stock index and Sukuk index returns), so both are integrated of the same order. The KPSS test for the null hypothesis of the level or trend stationarity against the alternative of non-stationarity is also applied to provide robust results. Using this test, we can easily reject the null hypothesis of stationarity for the levels of all series (Aloui, Hammoudeh, \& Hamida, 2015).

To find out whether a series of data is stationary or not stationary, visually, it can be seen from a plot or graph. If the fluctuation tendency around the average value with an amplitude that is relatively fixed or there is no visible trend (trend) up or down can be said stationary data. However, in determining the stationary or not distribution of data using graphics, usually different 
conclusions appear because the decisions taken are very subjective. Avoiding subjectivity in the calculation, a formal test is carried out in determining the stationary data, namely by using the unit root test (Unit Roots Test) using the Dickey-Fuller Test Augmented (ADF Test) method. This test is based on a comparison between $t$ statistics and Mac Kinnon Critical Values table, with notes or requirements that must be fulfilled as follows: $a$ ). If $t$ statistics for Mac $<$ Kon table are critical values, then $\mathrm{H} 0$ is accepted which means that the residual data is not stationary. b). If $t$ statistics $>t$ table Mac Kinnon Critical Values, then $\mathrm{HO}$ is rejected which means stationary residual data. This test is based on the comparison between the ADF probability value and the significance value of 0.05 or $5 \%$. By using the following conditions: a). If the ADF probability value is $<0.05$, Ho is rejected which means stationary residual data. b). If the ADF probability value $>0.05$ then Ho is accepted which means the residual data is not stationary

\section{Return Calculation}

The calculation of returns is essential for an investor. For that matter, so in this study, the announcement of Sukuk is an event, so, set the event date as the day to 0 . The return itself is defined as the daily stock market closing price at $t$ time and market return using the Composite Stock Price Index (CSPI). So that it can be formulated as follows:

$R_{i, t}=\frac{P_{i, t}-P_{i, t-1}}{P_{i, t-1}}$

Note: $R_{i, t}=$ return of stock $\mathrm{i}$ at the time $\mathrm{t}$

$P_{i, t}=$ the close price of stock $\mathrm{i}$ at the time $\mathrm{t}$

$P_{i, t-1}=$ the close price of stock $\mathrm{i}$ at the time $\mathrm{t}-1$

\section{Autoregressive Conditional Heteroscedastic Model (ARCH) and Generalized Autoregressive Conditional Heteroscedastic (GARCH)}

Engle first introduced the Autoregressive Conditional Heteroscedastic (ARCH) model in 1982. The ARCH model can describe characteristics in finance. In the ARCH Model, there are two types of models arranged, namely the average model and the variance model. The ARCH model is used to produce a systematic model of volatility. Specifically, an ARCH (p) model has the following functions:

$a_{t}=\sigma_{t} \epsilon_{t}$

$\sigma_{t}^{2}=\sigma_{0}+\alpha_{1} a_{t-1}^{2}+\ldots . .+a_{p} a_{t-p}^{2}$

$\epsilon_{t}$ is an independent variable that is independent and identical to the mean zero and variance $1,>0$, and 0 for $i=0$. The phenomenon of volatility clustering or defined as the period in which the price of the stock shows wia de swing in a 
certain period and is usually followed by periods of relative calm always occurring in financial data, whether it is stock price data, inflation or otherwise. Engle (1982) introduces a research model called the Generalized Autoregressive Conditional Heteroscedastic (GARCH) model which is a development of the ARCH model. This GARCH model is useful if the model experiences time-varying volatility in financial assets. In the development in the GARCH model i,t is actually crucial for modeling variations in volatility. If the conditional variance does not follow the normal distribution, the GARCH model cannot explain the entire leptokurtosis in the sample data used and it is better to use non-normal distributions such as Student $t$, normal-lognormal distribution, or exponential GARCH (EGARCH) models in order to capture the high conditional moment. Aloui, Hammoudeh and Hamida (2015) also used the EGARCH model to estimate the model, where the EGARCH model is suitable for accounting for volatility clustering and asymmetry in the Sharia time series.

The EGARCH $(1,1)$ model is a development of the GARCH $(1,1)$ model. The empirical model on EGARCH can capture asymmetric effects on stock market returns and explore conditional moments. The basic structure of the GARCH $(1,1)$ model is stated in equation 3.2 , as follows:

$y_{t}=l_{t} \gamma+\propto \varepsilon_{t-1}^{2}$

$\varepsilon_{t}=v_{t} \sigma_{t}$ dan $v_{t} \sim N(0,1)$

The equation 3.2 is the function of exogenous or predetermined variables $l_{t}$ and the error term is written as $\varepsilon$.

\section{EGARCH Model (Exponential GARCH)}

The EGARCH model is the result of the development of the GARCH model. Where it is known that the GARCH model cannot capture asymmetric effects that occur when the effects on volatility differ in two types of announcements are announcements that are good news and bad news. Asymmetric effects occur when downward movements in the market in a market not followed by higher volatility than with upward movement from the same direction. In other words, there will be the impact of different volatility between the two announcements is the announcement which is good news and bad news. Effects that occur in volatility resulting from bad news announcements in the coming period greater than the effect caused by good announcements news in the next period. Exponential asymmetric on volatility is an impact at the time shock. Therefore, the equation for a conditional variance must be done in another form. The EGARCH (Exponential GARCH) model developed to estimate the effect of this asymmetric. The EGARCH model formulated is as follows: 
$\log \left(\sigma_{t}^{2}\right)=\omega+\beta \log \log _{t-1}^{2}+\gamma \frac{\varepsilon t-1}{\sigma t-1}+\alpha \frac{\varepsilon t-1}{\sigma t-1}-\frac{\overline{2}}{\pi}$

On the right side of equation 3.6 where is conditional variance since the initial estimation period to calculate variance in some announcements in the relevant past. is parameter estimation. Because it is a model, then significant profits the EGARCH model is even if the parameter is negative then it will be positive. Parameters are presented as the magnitude of the effect of the symmetric effect model. As a measure of persistence in no conditional volatility depends on something that happens in the market. Parameter size asymmetric effect or leverage effect, this parameter is significant that the EGARCH model allows testing asymmetric. If $=0$ then the model expressed as symmetric. Whereas, if, then positive shocks (good news) cause volatility to decrease rather than adverse shocks. When stating that positive change is more destabilizing than negative change.

$\log \left(\sigma_{t}^{2}\right)=\omega+\beta \log \log _{t-1}^{2}+\gamma \frac{\varepsilon t-1}{\sigma t-1}+\alpha \frac{\varepsilon t-1}{\sigma t-1}-\frac{\overline{2}}{\pi}+\beta$ event + Bvol (3.7)

Because in this study will also test whether the announcement event This Sukuk influences volatility in addition to what trading volume have an influence also on the volatility of stock returns equation 3.7 can be developed into equation 3.7.

\section{The Selecting Test of Model Choosing}

In data analysis, usually, some models can be obtained to represent data in the analysis. Among the several models obtained, then selected one of the best models: 1). Akaike Information Criterion (AIC) Test and Information Criterion (SIC) Schwarz Test: The criteria for two AIC tests and the SIC test are model selection criteria based on standard errors. AIC test is used to test the accuracy model. The Augmented Dickey-Fuller (ADF) test is performed and the lag lengths are determined by the Akaike's Information Criteria (AIC) (Hassan et al., 2018).

The model is said to be good if the AIC and SIC values are minimum. 2). Significant test: A variable is said to be significant if the variable has a real influence on other variables, so that significance is a thing that is vital in a model. If in a model, there are many significant independent variables then that means the model is built is a good model because the independent variables proposed have a real influence in a model. More variables significant independent in a model then the model is the model good when compared to other models 3). The Lagrange multiplier test (LM Test): LM test is a test to see the ARCH effect in the model. This LM test is the first step to building the ARCH- 
GARCH model. The purpose of this LM test is to examine the presence of elements heteroskedasticity (dynamic volatility). The basic idea of LM test is that variance residuals are not only a function of variables but depend on residual squared in the previous period. If the probability value obs * $\mathrm{R} 2$ is smaller than the confidence level $(=5 \%)$ then it can be said that in the model, there is an ARCH effect. So that estimates can be made using ARCH or GARCH models.

\section{Hypothesis Testing}

The z-statistic test is used to indicate significant at $10 \%, 5 \%$, and $1 \%$ levels (Mohamed et al., 2015). This test is based on the differences between $\mathrm{z}$ counts and $\mathrm{z}$ tables, by observing the following conditions: a). If $\mathrm{z}$ count $<\mathrm{z}$ table then $\mathrm{HO}$ is accepted and $\mathrm{Ha}$ is rejected, meaning that Individual independent variables do not affect variables dependent. b). If $\mathrm{z}$ count $>\mathrm{z}$ table, then $\mathrm{HO}$ is rejected and $\mathrm{Ha}$ is accepted, meaning variable individually independent affects the dependent variable. The z-statistic test can also be based on a comparison between values significance of $\mathrm{z}$ with a significance value of 0.05 , considering the conditions as follows: a). If the significance of $\mathrm{z}<0.05, \mathrm{H} 0$ is accepted, meaning the independent variable affects the dependent variable. b). If the significance of $\mathrm{z}>0.05, \mathrm{H} 0$ is accepted, meaning the independent variable does not affect the dependent variable.

\section{RESULTS AND DISCUSSION}

The return volatility of the stock is the return movement observed by seeing the event occurred, both bad and good news. The research aims to examine the return volatility during the Sukuk issuance and the effect of volume on the return volatility of the stock. The data observation taken is the close price to calculate the return movement, then the volume activity of stock to see the effect of volume to the return volatility. We used the windows Days-30 until Days +30 and Days- 100 and Days +100 . Furthermore, the Days-30 until days +30 is symbolized in Dummy 1, while the other used dummy 0 . The statistical tool that we used is the EViews 7.0. It helps us to analyze the EGARCH model.

The descriptive analysis is the analysis that we used to provide the general description systematically, based on factual and accurate data. It depicts the variables like the return and volume, entailing the number of observations, minimum, maximum, mean, and deviation standard (H. H. Mohamed et al., 2015). Table 3 presents the results of descriptive statistic, it depicted that the average of daily return when the event at D-100 and D+100 for the company Matahari Putra Prima (MPPA) is 0.0020, while the BLTA was 0.0027, ELTY was 0.0081 , ISAT on 2012 was 0.0011 , ADHI was 0.0051 , ADMF was 0.0011 . 
Table 3. Descriptive statistic

\begin{tabular}{cccccc}
\hline Series & $\mathrm{N}$ & Mean & $\begin{array}{c}\text { Deviation } \\
\text { Standard }\end{array}$ & Min & Max \\
\hline RMPPA & 201 & 0.0020 & 0.0024 & -0.0655 & 0.0892 \\
RBLTA & 201 & 0.0027 & 0.0416 & -0.0906 & 0.2514 \\
RELTY & 201 & 0.0081 & 0.0592 & -0.0164 & 0.3097 \\
RISAT09 & 201 & 0.0005 & 0.0217 & -0.0603 & 0.0792 \\
RMAPI & 201 & 0.0031 & 0.0259 & -0.0574 & 0.1466 \\
RFPNI & 201 & -0.0010 & 0.0397 & -0.1156 & 0.3442 \\
RMYOR & 201 & 0.0026 & 0.0225 & -0.0639 & 0.0755 \\
RISAT12 & 201 & 0.0011 & 0.0244 & -0.0652 & 0.1186 \\
RADHI12 & 201 & 0.0051 & 0.0255 & -0.0744 & 0.1195 \\
RADMF & 201 & -0.0011 & 0.0156 & -0.0942 & 0.0810 \\
RADHI13 & 201 & 0.0057 & 0.0328 & -0.0986 & 0.1616 \\
RAISA & 201 & 0.0019 & 0.0291 & -0.0846 & 0.1127 \\
RSMRA & 201 & 0.0017 & 0.0351 & -0.1309 & 0.1111 \\
\hline
\end{tabular}

Then, ADHI in 2013 was 0.0057 , AISA was 0.0019 , and SMRA was 0.0017. Also, the standard deviation was also provided, the lowest was ADMF while the highest was ELTY. We also presented the minimum and the maximum in Table 3. Based on that Table, it indicates that the stock return from the companies who issued Sukuk was random and volatile because the deviation standard of each company's return was higher than the mean return of those.

We also examined the stationarity test using the Augmented Dickey-Fuller Test; the results meet the stationarity assumptions based on some indicators such as the probability value is 0.000 (MPPA), in which the ADF is lower than the significant level 0.05 , so the $\mathrm{HO}$ is rejected. It means the return of MPPA is stationarity on the first difference. It also happened in the ADF of BLTA and other remaining stocks. Due to the limitation of the page, we did not provide the Table in this paper. Then the SIC, AIC, and Log-Likelihood Model EGARCH due to page limitations are not presented here. Based on that Table, the RMPPA based on the Akaike Information Criterion (AIC) and the Schwart Information Criterion (SIC), we can see that EGARCH 1.2 has the smaller AIC and SIC values than the other EGARCH model and has the Loglikelihood value 404,882.

Furthermore, Table 4. presents the regression of EGARCH 2.1 models for the RMPPA, RBLTA, RISAT, RMAPI, RMPNI, RISAT, RMYOR, RISAT12, RADHI12, and RADMF. We found that the EGARCH model for ISAT09 has an asymmetric effect. In Table 4 the EGARCH model 2 has a significant result for the $\beta$ coefficient. The sign is positive, it indicates that the GARCH component in this model is accepted by time-varying volatility. In the model, there is an asymmetric effect where $\gamma$ $>0$ and statistically significant on 1\%, thus EGARCH for MAPI has an asymmetric effect. The model for MYOR has time-varying volatility and asymmetric effect. This also happened for ISAT12. ADHI12 also has timevarying volatility and asymmetric effect. ADMF also has the same results. 
Furthermore, the model has time-varying volatility and EGARCH for ADHI has the asymmetric effect. AISA and SMRA also have time-varying volatility and asymmetric effect.

Table 4. EGARCH Model 2.1 - Independent Variable = LOG (GARCH)

\begin{tabular}{cc}
\hline Company & Coefficient \\
\hline RMPPA & 0.002 \\
& $(0.002)$ \\
RBLTA & 0.001 \\
& $(0.002)$ \\
RISAT09 & 0.003 \\
& $(0.002)$ \\
RMAPI & 0.0007 \\
& $(0.002)$ \\
RFPNI & 0.003 \\
& $(0.002)$ \\
RMYOR & -0.0007 \\
& $(0.001)$ \\
RISAT12 & -0.0009 \\
& $0.001)$ \\
RADHI12 & 0.0009 \\
& $0.002)$ \\
RADMF & -0.0009 \\
\end{tabular}

Note: The standard errors in parentheses

According to Mohamed, Masih, \& Bacha (2015), the Z-Statistic test is used to examine the effect of the independent variable on the dependent variable by using the degree of $\alpha$, whether the effect is significant at $10 \%, 5 \%$, or $1 \%$ level. The hypothesis alternative is significant if the $\mathrm{z}$ value $<0.05$, so the independent has a significant relationship to the dependent variable. While, if the $\mathrm{z}$-value $>$ 0.05 , we accept the null hypothesis. In this research, the relationship between the event of Sukuk announcement and trading volume is examined.

Then, the effect of the event to stock return volatility of Matahari Putra Prima (MPPA) according to the analysis is negative (-0.95), but it is not significant. While the effect of trading volume on the stock return volatility MPPA based on the $\mathrm{z}$-statistic is positively insignificant by the coefficient 0.000002 . For the next company (Berlian Laju Tanker/BLTA), we found that the relationship of the event to return volatility is positive but not significant. While the trading volume has a positive $(0.00005)$ relationship significantly to the return volatility. Then, Bakrie Development (ELTY) where the event has a positive correlation but not significant to return volatility. While the trading volume has a positive relationship toward the return volatility.

For Indosat Company in 2009 (ISAT09), we found that the stock return volatility is negatively affected by the trading volume $(-0.000004)$, for the event 
is positively insignificant (0.04). While Mitra Adi Perkasa (MAPI) we found the same results. Lotte Chemical Titan (FPNI), as we can see from Table 4.15, only trading volume has a positive $(0.00001)$ relationship significantly toward the return volatility. Trading volume has a negative relationship significantly to the return volatility in the Mayora company (MYOR). The event has a negative coefficient but not significant.

The event also has a positive insignificant relationship to return volatility, but trading volume has a positive correlation significantly for ISAT 2012. At ADHI 2012, Table 5 presents that the event has a negative relationship to return volatility albeit insignificant, while trading volume has a positive and significant relationship to return volatility. The details are presented in Table 5 below:

Table 5. Hypothesis Testing by using z-statistic

\begin{tabular}{ccc}
\hline Company & Model 1 & Model 2 \\
\hline MPPA & -0.95 & 0.00002 \\
BLTA & 0.17 & $0.00003^{* * *}$ \\
ELTY & 0.12 & $0.000003^{* *}$ \\
RISAT09 & 0.04 & $-0.00004^{* *}$ \\
MAPI & 0.04 & $0.00002^{* * *}$ \\
FPNI & 0.06 & $0.000001^{* * *}$ \\
MYOR & -0.11 & $-0.0001^{* * *}$ \\
ISAT12 & 0.01 & $0.000001^{* *}$ \\
ADHI12 & -0.02 & $0.000003^{* *}$ \\
ADIRA MULTI FINANCE & $-0.55^{* * *}$ & -0.00008 \\
ADHI13 & -0.02 & $0.00003^{* * *}$ \\
AISA & -0.02 & $0.000002^{* * *}$ \\
SMRA & -0.31 & -0.00007 \\
\hline
\end{tabular}

Note: Model 1 and 2 the dependent variable is the return volatility; model 1 the independent is an event, while mode 2 the independent is trading volume. $p<0.001^{* * *}$ is significant at $1 \%, \mathrm{p}<0.005^{* *}$ is significant at $5 \%, \mathrm{p}<0.01^{*}$ is significant at $10 \%$.

Only Adira Multi Finance which has a negative significant relationship between the Sukuk issuance and returns volatility, in this company the volume has a negative relationship but insignificant to return volatility. Then, ADHI 2013 shows that event and trading volume positive and not significant to return volatility. Tiga Pilar Sejahtera (AISA) depicts that trading volume has positive and significant to return volatility. Lastly, Summerecon Agung (SMRA) shows that event and volume have negative insignificantly to return volatility. 
Based on the model testing for each of the companies which issued Sukuk, the event has positive in some companies and negative relationship for other companies toward the return volatility, but mostly insignificant. So, the Sukuk announcement does not affect the return volatility. We can interpret that Sukuk is not the considering event for the investors, so they did not respond to Sukuk both positively and negatively.

While for the time-varying volatility on the stock return volatility we found that some companies which issued the Sukuk have time-varying volatility in their return volatility. Most of EGARCH models have positive $\beta$ coefficient significantly. It means the increase and decrease (good news or bad news) have an asymmetric impact on the conditional variance of stock return.

Based on some companies issued Sukuk, we found that all stock return experience the asymmetric effect. The probability value of the $\gamma$ parameter is significant. The information that is absorbed by the market as the good news because the volatility changing is positive. Since the investors used the Sukuk issuance information to hold the action in the capital market.

Furthermore, some companies who issued Sukuk in terms of trading volume have both positive and negative correlations to return volatility. Those correlations could be interpreted that the Sukuk effects on reducing the trading volume in some companies with the negative sign, while the other companies who have a positive sign, the Sukuk enlarges the trading volume. To sum up, Sukuk can be both goods in some companies and bad news for other companies.

\section{CONCLUSION}

The stock is an alternative investment for the investors in their portfolio. Many considering factors that they used in the capital market. Surely, they would consider the risk and the return in their investment activities. Therefore, they desire a higher return. The event of Sukuk issuance is one of current Islamic instrument the Islamic field, where it did not have an impact on the stock return of companies which issued Sukuk. From many companies, only one company which has significant event regarding Sukuk-Adira Multi Finance. On behalf of the stock return for the companies which issued Sukuk have the asymmetric effect on their return volatility. All observed companies had asymmetric and leverage effects.

On the relationship between trading volume to stock return and volatility, by utilizing E-GARCH model, we enter the trading volume in the estimation model and calculate the variation of stock return volatility. We found that the trading volume on average has a relationship to stock return volatility during the observation. From all companies which have been examined, the majority 
trading volume from those companies has a significant impact on the return volatility. Albeit, few companies are not significant. Based on the EGARCH estimations, 13 models for 13 companies, each of companies have different EGARCH form each other even though they used same time observations ( $t-100$ until $t+100$ ).

Based on our research, the practical contribution of the managerial policy is the managers or companies did not need to worry about the risk (investors in the market) if they would like to issue Sukuk. it has no impact on the stock return volatility.

We are aware that this research contains some limitations such as: firstly, the window of this research is too wide and limited to one window only. Thus, further research may use the real effect by using a closer time. Secondly, in this research, we did not include the macro variables, as we know that macrofinancial factors have a more significant impact on the capital market.

\section{REFERENCES}

Aloui, C., Hammoudeh, S., \& Ben, H. (2015). Co-movement between sharia stocks and sukuk in the GCC markets : A time-frequency analysis. "Journal of International Financial Markets, Institutions \& Money," 69-79. https://doi.org/10.1016/j.intfin.2014.11.003

Aloui, C., Hammoudeh, S., \& Hamida, H. Ben. (2015a). Global factors driving structural changes in the co-movement between sharia stocks and sukuk in the Gulf Cooperation Council countries. North American Journal of Economics and Finance, 31,311-329. https://doi.org/10.1016/j.najef.2014.12.002

Aloui, C., Hammoudeh, S., \& Hamida, H. Ben. (2015b). Price discovery and regime shift behavior in the relationship between sharia stocks and sukuk: A two-state Markov switching analysis. Pacific Basin Finance Journal, 34, 121-135. https://doi.org/10.1016/j.pacfin.2015.06.004

Bhuiyan, R. A., Rahman, M. P., Saiti, B., Bin, G., \& Ghani, M. (2018). Does the Malaysian Sovereign sukuk market offer portfolio diversification opportunities for global fixedincome investors? Evidence from wavelet coherence and multivariate-GARCH. North American Journal of Economics and Finance, July, 1-13. https://doi.org/10.1016/j.najef.2018.07.008

Bhuiyan, R. A., Rahman, M. P., Saiti, B., \& Ghani, M. G. (2019). Co-movement dynamics between global sukuk and bond markets New insights from a wavelet analysis. International Journal of Emerging Markets. https://doi.org/10.1108/IJOEM-122017-0521

Godlewski, C. J., Turk-ariss, R., \& Weill, L. (2013). Sukuk vs . conventional bonds : A stock market perspective q. Journal of Comparative Economics, 41(3), 745-761. https://doi.org/10.1016/j.jce.2013.02.006

Hanefah, M. M., \& Sains, U. (2013). Sukuk: Global Issues and Challenges. Journal of Legal, Ethical and Regulatory Issues, 16(1), 107-120.

Haroon, O., Fatima, S., \& Rizvi, A. R. (2019). Dana Gas : The Sukuk Dispute. Asian Journal of Management Cases, 1-13. https://doi.org/10.1177/0972820119884395

Hassan, M. K., Paltrinieri, A., Dreassi, A., Miani, S., \& Sclip, A. (2018). The determinants of co-movement dynamics between sukuk and conventional bonds. Quarterly Review 
of Economics and Finance, 68, 73-84. https://doi.org/10.1016/j.qref.2017.09.003

Ibrahim, M. H. (2015). Islamic banks, Shari'ah-compliant investment and sukuk. PacificBasin Finance Journal, 34, 185-191. https://doi.org/10.1016/j.pacfin.2015.06.002

Khartabiel, G., Abu, A., Tunku, A., \& Tunku, S. (2019). Shari'ah-compliant Sukuk versus conventional bond announcements: is there a wealth effect? Review of Quantitative Finance and Accounting, 0123456789. https://doi.org/10.1007/s11156-019-00799-3

Kholis, N. (2010). Sukuk: Instrument investasi yang halal dan menjanjikan. La_Riba: Jurnal Ekonomi Islam, IV(2), 145-159.

Klein, P. O., Weill, L., \& Godlewski, C. J. (2017). How sukuk shapes firm performance. World Economy, 41(3), 699-722. https://doi.org/10.1111/twec.12509

Mahomed, Z., Ramadilli, S., \& Ariff, M. (2018). Sukuk announcement effects during financial crisis: the case for Indonesia. Journal of Islamic Accounting and Business Research, 9(4), 567-586. https://doi.org/10.1108/JIABR-10-2017-0143

Mohamed, H. H., Masih, M., \& Bacha, O. I. (2015). Why do issuers issue Sukuk or conventional bond? Evidence from Malaysian listed firms using partial adjustment models. Pacific Basin Finance Journal, 34, 233-252. https://doi.org/10.1016/j.pacfin.2015.02.004

Naufa, A. M., Lantara, I. W. N., \& Lau, W.-Y. (2019). The impact of foreign ownership on return volatility, volume, and stock risks: Evidence from ASEAN countries. Economic Analysis and Policy, 64, 221-235. https://doi.org/10.1016/J.EAP.2019.09.002

Smaoui, H., Mimouni, K., \& Temimi, A. (2019). The impact of Sukuk on the insolvency risk of conventional and Islamic banks. Applied Economics, 00(00), 1-19. https://doi.org/10.1080/00036846.2019.1646406

Wilson, R. (2008). Humanomics Article information: Innovation in the Structuring of Islamic Sukuk Securities, 24(3), 170-181.

Otoritas Jasa Keuangan, 2010. Statistik Pasar Modal. Minggu IV Desember 2010. www.ojk.go.id access at $13^{\text {th }}$ February 2014.

Otoritas Jasa Keuangan, 2011. Statistik Pasar Modal. Minggu IV Desember 2011. www.ojk.go.id access at $13^{\text {th }}$ February 2014.

Otoritas Jasa Keuangan, 2012. Statistik Pasar Modal. Minggu IV Desember 2012. www.ojk.go.id access at $13^{\text {th }}$ February 2014.

Otoritas Jasa Keuangan, 2013. Statistik Pasar Modal. Minggu IV Desember 2013. www.ojk.go.id access at $13^{\text {th }}$ February 2014. 